\title{
Bladder Carcinoma in a 24-Year-Old Patient: A Case Report and Review of the Literature
}

\section{Yirmi Dört Yaşındaki Hastada Mesane Kanseri: Olgu Sunumu ve Literatür Derlemesi}

\author{
(D) İlker Akarken, (D) Hayrettin Şahin, (D) Hüseyin Tarhan, (D) Hasan Deliktaş, (D) Mehmet Çetinkaya \\ Muğla Sıtkı Koçman University Faculty of Medicine, Department of Urology, Muğla, Turkiye
}

\begin{abstract}
Urothelial bladder carcinoma is a rare condition in young patients. Clinicians have less inclination to perform cystoscopy in this age group because benign causes of hematuria are more common. Thus, diagnostic delays of up to one year may occur. We report a 24-year-old male patient with urothelial bladder cancer. Clinical behavior and prognosis in young individuals are controversial. The definitions of "young patient" are highly variable and different World Health Organization pathological classification systems are used for reporting. Generally, it presents as a low-stage and low-grade disease, nevertheless, it may present with high-grade tumors, even with muscle-invasive cancer.
\end{abstract}

Keywords: Bladder cancer, Urothelial, Young patient, Review, Case

Öz

Ürotelyal mesane kanseri genç hastalarda nadir görülür. Bu yaş grubunda hematürinin bening sebepleri daha sık olduğundan, hekimler sistoskopi yapma konusunda çok istekli değildirler. Bu nedenle tanıda bir yıla varan gecikmeler yaşanabilmektedir. Yirmi dört yaşında erkek hastada, genç hastalarda klinik davranışı ve prognozu belirsiz olan ürotelyal mesane kanserini rapor ettik. "Genç hasta" terimi çok değişken olarak kullanılmış ve farklı WHO patolojik klasifikasyon sistemleriyle raporlanmıştır. Genel olarak hastalık düşük-derece ve evre ile seyreder ancak, yüksek dereceli hatta kasa invaze hastalık bile görülebilmektedir.

Anahtar Kelimeler: Mesane kanseri, Ürotelyal, Genç hasta, Derleme, Olgu

\section{Introduction}

Bladder carcinoma has been reported to be a common malignancy with an estimated 15580 deaths and 74690 new cases globally in 2013 (1). It is typically a disease of older individuals; the majority of patients are above 60 years of age at the time of diagnosis. Urothelial bladder carcinoma (UBC) is a rare condition in patients aged below 40 years, furthermore, much rarer in the first two decades of life with reported incidence rates of only $0.1 \%$ to $0.4 \%$ (2). There is controversy regarding the clinical behavior and prognosis of UBC in young patients.

\section{Case Presentation}

The patient was a healthy 24-year-old male who had no history of smoking or exposure to chemicals. He presented to our clinic after having painless macroscopic hematuria. Physical examination was unremarkable. The urinalysis was positive for blood cells and there were no signs of infection and, other laboratory tests were normal. Initially, the patient was sent for a urinary ultrasound scan which revealed a $2 \times 2$ centimeters hyper-echoic lesion on the right side of the bladder; both of the kidneys were normal. His urine was confirmed to be sterile by urine culture and cytology of the urine was negative for aberrant cells. Diagnostic cystoscopy confirmed the papillomatous lesion on the right side of the bladder at the 8 o'clock position (Figure 1). Soon after, deep transurethral resection of the lesion was carried out down to the muscle. The postoperative period was uneventful. Pathology of the lesion was reported as papillary urothelial neoplasm of low malign potential (PUNLMP) (Figure 2). Control cystoscopy at the $3^{\text {rd }}$ month has shown no recurrence in the follow-up; the next cystoscopy was planned for the $12^{\text {th }}$

Correspondence: İlker Akarken MD, Muğla Sıtkı Koçman University Faculty of Medicine, Department of Urology, Muğla, Turkiye Phone: +90 5068266788 E-mail: ilkerakarken@gmail.com ORCID-ID: orcid.org/0000-0002-2863-3112

Received: 16.08.2017 Accepted: 19.09.2017

Cite this article as: Akarken I, Şahin H, Tarhan H, Deliktaş H, Çetinkaya M. Bladder Carcinoma in a 24-Year-Old Patient: A Case Report and Review of the Literature. J Urol Surg 2018;5(3):197-199.

๑Copyright 2018 by the Association of Urological Surgery / Journal of Urological Surgery published by Galenos Publishing House. 


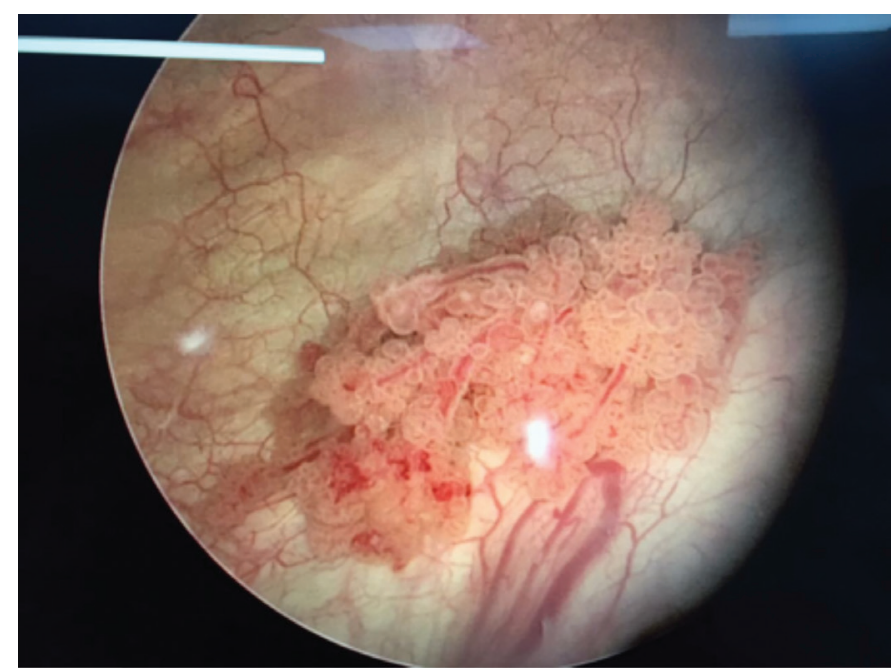

Figure 1. Cystoscopic view of the tumor

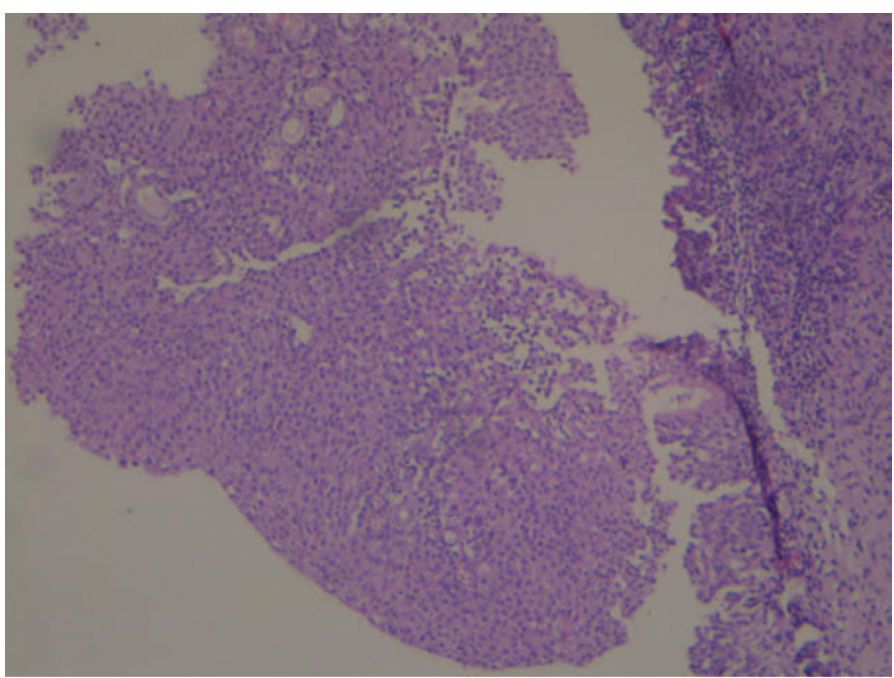

Figure 2. Microscopic view of the tumor

month. The informed consent was obtained from the patient for publication.

\section{Discussion}

UBC in young individuals is very rare and only $1 \%$ of cases are detected in the first 40 years of life. Its incidence dramatically increases with age. In people aged over the 70 years, the incidence rate of UBC is 15-20 times higher than in those aged $30-50$ years (3).

Nearly all patients with UBC typically present with macroscopic and painless hematuria (4). In this age group, the clinicians have less inclination to perform cystoscopy. In a study, cystoscopy was performed in $40 \%$ of children who presented with macroscopic hematuria and UBC was detected in only 1\% (5). Therefore, diagnostic delays of up to one year may occur. Ultrasound imaging is very sensitive for detecting UBC and proven to be a reliable diagnostic tool. Computed tomography is particularly useful for assessing the upper urinary system and distant metastasis. Urine cytology has limited use in the diagnosis of UBC because it has very low sensitivity.

There is controversy on the clinical behavior and prognosis of UBC in young patients which can be explained with several reasons. Firstly, the definitions of "young patient" are highly variable. The vast majority of the studies have included patients below 40 years of age as "young patient", while others have used 20 or 30 years of age as a cut-off point. Recently, in the age group below 20 years, the disease was found to have clinical and pathological features different from that in olders (6). Secondly, different World Health Organization (WHO) pathological classification systems have been used for reporting. The histopathological reporting classification system was last overhauled by the WHO in 2016.

The younger patients with UBC have low-stage and -grade disease while the incidence of high-grade tumors gradually increases with age. $\mathrm{Na}$ et al. (7) analyzed 42 patients and found pTa in 33, pT1 in 4, pT2 or higher in 5 and low-grade in 31, highgrade in 11 patients. Moreover Wang et al. (8) found that 5-year survival was better in young patients $(93.8 \%)$ than in older ones (85.1\%). The largest study, with more than 150 patients, showed that the vast majority of patients had PUNLMP (40.3\%), furthermore, UBC could be highly aggressive in 18\% of highgrade and muscle-invasive type tumors (9).

It is widely accepted that conversion of the 1973 WHO classification to the 2004 WHO classification would result in down-grading of a significant proportion of grade 1 tumors to PUNLMP (10). Especially in patients under 30 years of age, in whom grade 1 tumors predominate, it is likely that majority of urothelial carcinomas from studies published before the 2004 WHO system would have been classified as PUNLMP, as reported by Fine et al. (11). In that study, 23 UBC patients were reclassified according to the 2004 WHO classification system and more than half of tumors were found to be PUNLMP. It is reasonable to conclude that PUNLMP dominates in patients under 30 years of age. Even if PUNLMP may recur in up to $36 \%$ of patients, it has a low risk of progression (3.7\%) and this progression generally occurs as a low-grade pTa lesion (12). Another importance of the term is that the diagnosis of "cancer" can be avoided in young patients.

There have been some studies investigating the relationship between recurrence of UBC and age. Na et al. (7) showed that only $7.1 \%$ of patients under 40 years of age had recurrences, while $38 \%$ of patients over 60 years of age had recurrence. Moreover, Ozbey et al. (13) reported that the mean time to first relapse was 37.7 months in young patients and 9.9 months in older patients, therefore the older age group may have more rapid recurrence. 
Several studies were conducted to understand the molecular level why young patients had more low-grade and -stage tumors. Wild et al. (14) reported that genetic alterations which are frequently found in older patients are extremely rare under 20 years of age. Similarly, Owen et al. (15) showed lower epigenetic alteration rates in individuals under the age of 20 years.

Hematuria in young patients should be investigated in detail. By using the term PUNLMP, the diagnosis of "cancer" can be avoided and it is particularly important in young patients who usually have favorable outcomes. In the management of UBC in young patients, the grade and stage of the tumor are more critical than the age factor, as in older patients.

\section{Ethics}

Informed Consent: The informed consent was obtained from the patient.

Peer-review: Internally peer-reviewed.

\section{Authorship Contributions}

Surgical and Medical Practices: H.D., H.Ş., Concept: I.A., H.Ş., Design: I.A., M.Ç., Data Collection or Processing: I.A., H.T., Analysis or Interpretation: I.A., Literature Search: I.A., H.T., H.D., Writing: i.A.

Conflict of Interest: No conflict of interest was declared by the authors.

Financial Disclosure: The authors declared that this study received no financial support.

\section{References}

1. Siegel R, Ma J, Zou Z, Jemal A. Cancer statistics, 2014. CA Cancer J Clin 2014;64:9-29

2. Yossepowitch O, Dalbagni G. Transitional cell carcinoma of the bladder in young adults: presentation, natural history and outcome. J Urol 2002;168:61-66.
3. Fleshner NE, Herr HW, Stewart AK, Murphy GP, Mettlin C, Menck HR. The National Cancer Data Base report on bladder carcinoma. The American College of Surgeons Commission on Cancer and the American Cancer Society. Cancer 1996;78:1505-1513.

4. Lerena J, Krauel L, García-Aparicio L, Vallasciani S, Suñol M, Rodó J. Transitional cell carcinoma of the bladder in children and adolescents: sixcase series and review of the literature. J Pediatr Urol 2010;6:481-485.

5. Greenfield SP, Williot P, Kaplan D. Gross Hematuria in Children: A Ten-Year Review. Urology 2007;69:166-169.

6. Stanton ML, Xiao L, Czerniak BA, Guo CC. Urothelial tumors of the urinary bladder in young patients: a clinicopathologic study of 59 cases. Arch Pathol Lab Med 2013;137:1337-1341.

7. Na SW, Yu SH, Kim KH, Hwang EC, Jung SI, Kwon DD, Kang TW. The prognosis of patients less than 40 years with bladder cancer. J Cancer Res Ther 2014;10:710-714.

8. Wang $\mathrm{QH}$, Ji ZG, Li HZ, Fan H, Chen ZG, Shi BB, Fang Y. Clinicopathologic Comparison of Urothelial Bladder Carcinoma in Young and Elder Patients. Pathol Oncol Res 2016;22:67-70.

9. Compérat $E$, Larré $S$, Roupret $M$, Neuzillet $Y$, Pignot $G$, Quintens $H$, Houéde N, Roy C, Durand X, Varinot J, Vordos D, Rouanne M, Bakhri MA, Bertrand P, Jeglinschi SC, Cussenot O, Soulié M, Pfister C. Clinicopathological characteristics of urothelial bladder cancer in patients less than 40 years old. Virchows Arch 2015;466:589-594.

10. Samaratunga H, Makarov DV, Epstein JI. Comparison of WHO/ISUP and WHO classification of noninvasive papillary urothelial neoplasms for risk of progression. Urology 2002;60:315-319.

11. Fine SW, Humpherey PA, Dehner LP, Amin MB, Epstein Jl. Urothelial neoplasms in patients 20 years or younger: A clinicopathological analysis using the World Health Organization 2004 bladder consensus classification. J Urol 2005;174:1976-1980

12. Montironi R, Mazzucchelli R, Scarpelli M, Lopez-Beltran A, Cheng L. Morphological diagnosis of urothelial neoplasms. J Clin Pathol 2007;61:3-10

13. Ozbey I, Aksoy Y, Biçgi 0, Polat 0, Okyar G. Transitional cell carcinoma of the bladder in patients under 40 years of age. Int Urol Nephrol 1999;31:655-659.

14. Wild P, Giedl J, Stoehr R, Junker K, Boehm S, van Oers JM, Zwarthoff EC, Blaszyk H, Fine SW, Humphrey PA, Dehner LP, Amin MB, Epstein JI, Hartmann A. Genomic aberrations are rare in urothelial neoplasms of patients 19 years or younger. J Pathol 2007;211:18-25.

15. Owen HC, Giedl J, Wild PJ, Fine SW, Humphrey PA, Dehner LP, Amin MB, Epstein JI, Blaszyk H, Hughes D, Hartmann A, Stoehr R, Catto JW. Low frequency of epigenetic events in urothelial tumors in young patients. J Urol 2010;184:459-463. 